\title{
Antecedents, Consequences And Control Of Opportunistic Behavior In Strategic Networks
}

\author{
Muhammad Zafar Yaqub, University of Vienna, Austria
}

\begin{abstract}
In the Strategic Management literature, the problem of cooperation arising from conflicts of interest has been described as the problem of motivation. Under assumptions of self-interest, or its stronger forms (such as opportunism), collectively beneficial outcomes do not result for because of the actions motivated by the self interests of individual members. In this paper, the author presents a host of antecedents that can spur and/or facilitate such opportunistic pursuits in members of a strategic network. The influence of these antecedents has been reflected in the exante and ex-post phases of network life cycle. It is postulated that the problem can be resolved by securing an alignment in partners' interest which together with alignment in actions contributes to the bottom line through increased ability to yield an integrated response to the adaptation requirements stemming from disturbances in networks' environment. A detailed discussion been administered on how opportunism can be controlled through formal measures like contracts, TSIs, vertical integration and game theoretic stipulations, and the informal controls like relational norms, identification, and culmination of trust and commitment.
\end{abstract}

Keywords: Opportunism, Strategic Networks, Network Governance

\section{INTRODUCTION}

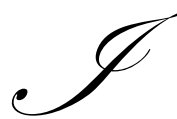

n 1984 GE and Rolls Royce formed a strategic alliance to manufacture jet engines for commercial airliners. The GE-Rolls Royce alliance seemed to be an ideal way of getting the two partners into markets where they had been weak, while enabling them to avoid some of the development costs required designing a new engine from the scratch. However, this ideal fit was scrapped in two years because the two companies' cooperation in making jet engines turned into competition. Both sides realized that cooperation would not be possible given the direct competition and the lack of trust between them (Wall Street Journal 1986).

Bleeke and Ernst (1993) reveal that managers typically choose direct competitors as partners in view of short-term synergy through consolidation of overlapping products and market positions. However, a significant number of such arrangements fail because individual partners' goals become misaligned with their collective goals, as manifested by the GE-Rolls Royce conflict. They act opportunistically by withholding important information, providing false information, or simply by cheating others (Park and Ungson, 2001) that eventually counts upon the networks' continuity as relationships marked by conflict, strife, competition and ongoing dis-agreements are clearly prone to breakup (Anderson and Jap, 2005). It is, however, important to bear in mind that such an opportunistic tendency is not unique to the competing partners; these are also not much uncommon among non-competing partners in a collaborative arrangement.

Several studies, involving hundreds of ongoing business relationships, offer rich insights into how seemingly good relationships go bad. The results suggest a striking phenomenon: 'Relationships that appear to be doing well are often the most vulnerable to the forces of destruction that are operating quietly beneath the surface of relationship' (Anderson \& Jap, 2005). Several economists (Kogut, 1988, 1991; Parkhe, 1993; Gulati et al,. 1994) 
have pointed to the growth of opportunism as the force that destabilizes inter-organizational ties (especially of the closed-ended type).

Opportunism refers to a lack of candor or honesty in transactions, to include a pursuit of self-interest with guile (Willaimson, 1985). Such a behavior may be exhibited, sequentially or simultaneously, by either one or both the parties in an exchange relationship (Joshi and Stump, 1999). It can be proactive and/or reactive. It may involve violation of contractual norms (the stronger form opportunism) or violation of relational norms (the weaker form opportunism). According to Brown et al. (2000), the partners can engage in opportunism even before actual formation of a relationship (Ex-ante opportunism), or they may behave opportunistically after the relationship has been launched (Ex-post opportunism). Ex-post opportunistic behaviors include withholding or distorting information to 'mislead, distort, obfuscate, or otherwise confuse' (Willamson, 1985; Ghoshal and Moran, 1996). It leads to the moral hazards like shirking and free-riding. Anyhow, both these types negatively impact the relationship where the former may even paralyze the formation of relationship and the later tempers the mutual trust, commitment and ultimately the spirit of cooperation.

Quite contrary to some organizational economists like Alchian and Demsetz (1972) who espoused that it is due to the basic self-interested action that firms or other structures become the efficient way of organizing, fairly a large number has stressed the dis-instrumental effects of this construct. Scholars have used a broad range of disciplines i.e. transaction-cost economics (Buckley and Casson, 1988), resource-based view (Eisenhard and Schcoonhoven, 1996), game theory (Gulati et.al., 1994), strategic behavior theory (Kogut, 1988), agency theory (Geiringer and Herbert, 1989), real option theory (Kogut, 1991) and learning theory (Hamel, 1991)- to describe the failure of network arrangements like strategic alliances, joint ventures etc. as a consequence of opportunistic hazards stemming from competitive collaboration.

Even though there is no shortage of studies and the facts of matter on the subject, the problem with studying the opportunism is rather the proliferation of explanations on the subject construct with little cross fertilization. The study of competition and cooperation is multifaceted and multidisciplinary, including disciplines from economics, political science, sociology, organization science, population ecology, business strategy etc. While the assumptions and approaches vary, these studies suggest that inter-firm cooperation and competition are embedded in social conditions or contexts that structure the 'rules of conduct' to govern cooperative and competitive behaviors. Although these theories are unique in their contribution to explaining opportunistic behavior, they mostly adopt contingency approaches, with each theory explaining a small facet of the problem in context of some specific form of strategic networks. So far, there has been little effort to integrate these multiple views and to look for the underlying theoretical constructs that could tie these eclectic explanations together. This explains why the field still lacks a systematic and integrated explanation of opportunistic behavior in strategic networks.

In this paper, I have presented an integrated explanation that covers most the key issues related to the problem of opportunism discussed in the previous studies. Accordingly, multiple perspectives introduced in earlier studies constitute the theoretical foundation in my effort to present an exhaustive explanation of the dynamics of opportunistic behavior in strategic networks. The first section presents a detailed account of the contingencies that foster opportunistic predispositions in the network partners. The second section discusses the adversaries caused due to such behaviors and the third section presents some measures to effectively control this problem. The final section highlights some avenues for future research over and above concluding the whole discussion.

\section{ANTECEDENTS OF OPPERTUNISM}

Table 1 outlines various antecedents of opportunistic behavior in strategic networks. These have been classified into the behavioral and/or structural antecedents with the presumptions that the behavioral factors spur opportunism whereas the structural factors facilitate the opportunistic players in their pursuits to maximize their self interests. The table also portrays influence of these antecedents in the ex-ante and ex-post phases of network life cycle along with reporting the useful analytical perspectives and references. As is revealed from the table, some of these factors operate throughout both the phases of network life cycle whereas the others have more influence on any one of these phases. In the rest of this section, I will deal with the question: how these variables spur and/or facilitate opportunism in the participants of strategic networks? 
TABLE 1

The Antecedents of Opportunism in Strategic Networks

\begin{tabular}{|c|c|c|c|c|}
\hline \multirow[b]{2}{*}{ Antecedent } & \multicolumn{2}{|c|}{ Phases of Network LC } & \multicolumn{2}{|l|}{ Useful Analytical } \\
\hline & Ex- ante & Ex-post & Perspectives & Useful References \\
\hline \multicolumn{5}{|l|}{ Behavioral } \\
\hline History of Collaboration & $\S$ & $\S$ & $\begin{array}{l}\text { Strategic Behavior Theory } \\
\text { Relational View } \\
\text { Game Theory }\end{array}$ & $\begin{array}{l}\text { Oxley 1997, Gulati } 1998 \\
\text { Ring 2002, Telser } 1980 \\
\text { Park \& Ungson } 2001 \\
\text { Ring \& Van De Van } 1994\end{array}$ \\
\hline Perceived Life \& LTV & $\S$ & $\S$ & $\begin{array}{l}\text { Strategic Behavior Theory } \\
\text { Game Theory } \\
\text { Relational View }\end{array}$ & $\begin{array}{l}\text { Das \& Tang } 2000 \\
\text { Taylor 1987,Kronman } 1985 \\
\text { Klien \& Leffler } 1981\end{array}$ \\
\hline $\begin{array}{l}\text { Perceived Partnership } \\
\text { Uncertainty } \\
1995\end{array}$ & $\S$ & $\S$ & Transaction Cost Economics & $\begin{array}{l}\text { Reve \& Stern } 1976 \\
\text { Bensaou \& Venkatraman }\end{array}$ \\
\hline $\begin{array}{l}\text { Chauvinism/ } \\
\text { Particularism }\end{array}$ & & $\S$ & $\begin{array}{l}\text { Agency Theory } \\
\text { Game Theory } \\
\text { Strategic Behavior Theory }\end{array}$ & $\begin{array}{l}\text { Aldrich \& Mardson } 1988 \\
\text { Baker 1993, Morten 1957, } \\
\text { Jensen-Mecklin, } 1976\end{array}$ \\
\hline $\begin{array}{l}\text { Perceived Fairness and/or } \\
\text { In-equity aversion (IA) }\end{array}$ & $\S$ & $\S$ & $\begin{array}{l}\text { Game Theory } \\
\text { Relational View } \\
\text { Strategic Behavior Theory }\end{array}$ & $\begin{array}{l}\text { Fehr \& Schmit } 1999 \\
\text { Gulati \& Nickerson 2007, } \\
\text { Hill } 1990\end{array}$ \\
\hline Conflict resolution behaviors & & $\S$ & $\begin{array}{l}\text { Game Theory } \\
\text { Relational View }\end{array}$ & $\begin{array}{l}\text { Anderson \& Jap } 2005 \\
\text { Zajac and Olsen, } 1993\end{array}$ \\
\hline \multicolumn{5}{|l|}{ Structural } \\
\hline $\begin{array}{l}\text { Time Boundedness } \\
\text { (Open vs Closed) }\end{array}$ & $\S$ & $\S$ & $\begin{array}{l}\text { Strategic Behavior Theory, } \\
\text { Game Theory } \\
\text { Relational View }\end{array}$ & $\begin{array}{l}\text { Parkhe } 1993 \\
\text { Telser } 1980 \\
\text { Axelrod } 1984\end{array}$ \\
\hline Asset specificity & & $\S$ & $\begin{array}{l}\text { Transaction cost economics } \\
\text { Strategic behavior theory } \\
\text { Resource-based view }\end{array}$ & $\begin{array}{l}\text { Williamson } 1985 \\
\text { Kogut 1988, Klein } 1995 \\
\text { Doney and Cannon } 1997\end{array}$ \\
\hline Resource characteristics & & $\S$ & $\begin{array}{l}\text { Resource-based View } \\
\text { Learning Theory }\end{array}$ & $\begin{array}{l}\text { Hamel et al. } 1989 \\
\text { Byrne et. al. } 1993\end{array}$ \\
\hline $\begin{array}{l}\text { Distribution of Ownership } \\
\& \text { Decision Rights }\end{array}$ & & $\S$ & $\begin{array}{l}\text { Property Rights Theory } \\
\text { Relational View, TCE }\end{array}$ & $\begin{array}{l}\text { Eccles \& Crane } 1987 \\
\text { Rockert \& Short } 1990\end{array}$ \\
\hline Information Asymmetry & $\S$ & $\S$ & $\begin{array}{l}\text { Transaction Cost Economics } \\
\text { Strategic Management Theory } \\
\text { Game Theory }\end{array}$ & $\begin{array}{l}\text { Alstyne } 1997 \\
\text { Hennart and Reddy's } 1997\end{array}$ \\
\hline $\begin{array}{l}\text { Nature of } \\
\text { Interdependence }\end{array}$ & $\S$ & $\S$ & $\begin{array}{l}\text { Transaction Cost Economics } \\
\text { Game Theory }\end{array}$ & $\begin{array}{l}\text { Alchian \& Demsetz } 1972 \\
\text { Axelrod } 1984\end{array}$ \\
\hline Power Asymmetry & $\S$ & $\S$ & $\begin{array}{l}\text { Agency Theory, Game } \\
\text { Theory, TCE, Strategic } \\
\text { Behavior Theory }\end{array}$ & $\begin{array}{l}\text { Lazzirini et. al. } 2006 \\
\text { Powell } 1990 \\
\text { Hamel et al. } 1989\end{array}$ \\
\hline Incentive Structure & & $\S$ & $\begin{array}{l}\text { Transaction Cost Economics } \\
\text { Game Theory }\end{array}$ & $\begin{array}{l}\text { Park \& Ungson } 2001 \\
\text { Porter and Fuller } 1985\end{array}$ \\
\hline Governance Structure & & $\S$ & $\begin{array}{l}\text { Transaction Cost Economics } \\
\text { Relational View }\end{array}$ & $\begin{array}{l}\text { Williamson } 1979 \\
\text { Reuer and Arino } 2006 \\
\text { Lieblien et al. } 2002\end{array}$ \\
\hline
\end{tabular}

$\S$ shows that the antecedent affects (positively or negatively) during this phase 


\section{BEHAVIORAL ANTECEDENTS}

\section{History Of Collaboration}

The collaborative relationships in strategic networks evolve through multiple rounds of cooperation spreaded over the span of its lifetime. Ring and Van de Van (1994) noted: 'each stage of alliance evolution runs through a cyclical process of negotiations-commitment-and execution according to the partner's evaluations of the efficiency and effectiveness of the alliance'. The partners are engaged in a continuous appraisal of the collaboration with respect to complementarity of contributions, benefits and the changed priorities in strategic interests across different stages of network life cycle (Park and Ungson, 2001). The survival of such strategic networks depends on the focal actor's adaptive capabilities over the course of network's life cycle (Gulati et al., 2005). Over time, a focal firm may avoid partners who have demonstrated a propensity for opportunistic behavior in the prior encounters, and retain those who have not. Therefore, partners who recognize the downfalls of cheating will be less likely to engage in opportunistic behavior (Park \& Ungson, 2001). As such, recurrent interaction with a partner leads to an expectation of behavior superior to that of an untested partner (Gulati and Nickerson, 2007). That is why repeat alliances present less (ex-ante) adverse selection problems in partner choice (Oxley, 1997) as well as less (ex-post) moral hazards (Gulati, 1998) than first time alliances because a partner's behavior is more predictable as is its competence for delivering the expected contributions (Ring, 2002). As such, the threat of opportunism is negatively associated with firms' prior collaborative histories with one another since the threat of breaking off the relationship serves as a self-enforcing sanction (Telser, 1980).

\section{Perceived Life And LTV Of Network}

Partners' expectations for the network's future strongly affect their predispositions to opportunistic behavior. In some (if not most often) cases, members join a network without considerable ex-ante optimism. Consequently, they perceive and take this collaboration as a short-lived endeavor. For them, (certain and tangible) short-run benefits outweigh the (intangible and uncertain) long-run benefits. This trade-off between short-term and long-term gains is a natural point of tension for many business relationships (Das and Teng, 2000). In general, if the partners in a relationship are too short-term oriented, they expect the networks to dissolve due to their own or other partners' cheating, or expect lower magnitude of aggregate gains over the life time of network. In this situation, the parties in exchange will not only try to (ex-ante) negotiate for undue terms but will also feel to have an incentive to (ex-post) exploit each other as quickly as possible and exit the relationship. Kronman (1985) noted: 'manufacturers will be unwilling to make the short-term sacrifices necessary to preserve the relationship if they do not expect the relationship to be profitable over the long-run'. On the other hand, if the long-term payoffs from cooperation are perceived to be sufficiently high, then cooperation can be sustained even among acutely self-interested players (Abreu, 1988; Klein and Leffler, 1981; Taylor, 1987; Telser, 1980).

\section{Partnership Uncertainty}

The uncertainty that a focal firm perceives about its relationship with a business partner(s) (Bensaou \& Venkatraman 1995) does not only (ex-ante) delays, paralyzes or causes an abandonment in the alliance formation but also increases the (ex-post) likelihood of moral hazards as the partner(s) will assume a transactional mode rather then developing high relationality. High asset specificity and mutual trust reduce partnership uncertainty and create a desirable transaction climate- the sentiments that exist among transacting parties whereby the parties share a unit bonding or belongingness (Reve \& Stern, 1976).

\section{Chauvinism/Particularism: A Key Agency Issue}

Although network organizations attempt to integrate across formal boundaries (Baker, 1993), group differentiation and in-group bias may still amplify excessive compartmentalization leading to goal displacement (Merton, 1957) and reduced integration (Alstyne, 1997). Even though these networks are purposive social systems for directing collective action towards common goals (Aldrich and Mardsen, 1988), yet the agents tend to forge identities for themselves. Boundary spanners or alliance managers experience 'dual citizenship' of affiliation: one with the network organization and the other with their parent companies and if they get predisposed to Chauvinism 
(Arendt, 1945) - an extreme and unreasoning partisanship on behalf of a group to which one belongs, especially when the partisanship includes malice and hatred towards a rival group- they become more interested in (ex-post) maximization of interests of their principles rather then the network as a whole. The situation may worsen if the parent firm(s) tries to fit network operations with their own long-term strategic goals inducing alliance managers to be even more concerned about local interests as opposed to adapting to market changes (Park and Ungson, 2001). Such a predisposition in agency relationship causes high agency costs which can be divided into the following components (Jensen-Mecklin, 1976);

Monitoring costs: costs for the principal to follow up the actions of the agent

Bonding costs: cost invested to maintain the agency relationship

Residual loss: the difference between the agent's performance and the performance that would have been obtained by the principal doing the task himself.

\section{Perceived Inequity-Aversion And Fairness}

Inequity aversion is the preference for 'fair rewards' and 'fairplay'. Players with such tendencies would prefer receiving nothing to receiving a reward awarded inequitably. (Fehr \& Schmidt 2000) describe two forms of IA as;

Disadvantageous IA (envy): disliking if another individual receives more than you Advantageous IA (guilt): disliking if you (in-equitably) receive more than another individual (i.e. overcompensation)

In pluralist players, the disadvantageous IA induces a resolve to sacrifice potential gain(s) to block another (opportunistic) player from (unduly) receiving a superior reward. This, apparently self-destructive, response is essential in creating an environment in which fairness equilibrium can thrive. Without IA's rejection of injustice, stable co-operation would be harder to achieve/maintain as there would be more opportunities to succeed for free riders. Additionally, if some partner is kind enough to behave fairly despite the opportunities to maximize his interest by behaving opportunistically (opportunity cost of fairness), the other players should also reciprocate with kindness so as to ensure (ex-post) fairness equilibrium. Such an approach goes a long way in making these relationships more like polygamous friendships than monogamous marriages.

The co-sharing of reputation for being trustworthy and inequity-averse (if not compassionate) partner is important for the culmination of ex-ante trust and commitment which reduces the fears and chances of adverse selection and thus facilitates the formation of collaborative arrangements. This heightens the network performance when augmented with co-sharing of predispositions of general trust. Even though the proactivity of players featuring grater propensity to general trust causes a greater ex-post inducement in other players to react positively following the 'norms of reciprocity', yet it also makes them more vulnerable to a game-theoretic behavior from the opportunistic players especially in the cooperation cycles towards the terminal stages of network life cycle. If the opportunistic players feature a fly-by-night predisposition and do not expect to be a part of future alliance(s) with these players, they may ignore the loss of reputation caused due to such cheating. Hill (1990) suggests that opportunism is viable if the future is not important to the provoker. Therefore, opportunistic hazards increase when social mobility increases i.e. individual members perceive exchanges in a non-recurring manner.

\section{Conflict Resolution Behaviors}

When two or more parties, with perceived incompatible goals, tend to undermine each other's goal-seeking capability, they are experiencing conflict. As 'recurring conflict is inevitable', a clash of interests, values, actions or directions often spark a conflict in networks at all levels-(micro (interpersonal), meso (group) and macro (networkwide)- with a host of structural, process, cultural and situational variable contributing to the state of conflict. Conflict-aversion could not be considered a good predisposition as good relationships often survive "functional crises" - potential conflicts that are ultimately constructive because the partners come together and work out their issues. For this to emerge, there has to be a strong resolve to turn problematic incidents into opportunities for improvement geared to nurture the relationship and remind the parties of what is good for and among them. Therefore, instead to 'win' conflict it is better to resolve such conflicts by finding some win-win solution through 
collaborative conflict resolution. If partners manage to establish social norms for joint value maximization, they pursue joint searches for satisfactory outcomes to conflicting situations and can easily escape the disintrumental effects of these conflicts (Zajac and Olsen, 1993). All this is quite possible under (power) symmetrical structural arrangements as, in the asymmetrical/power relations, there is a strong temptation to win the conflict in order to maximize one's own outcomes at the cost of other's leading to the erosion of trust and commitment.

\section{STRUCTURAL DETERMINENTS}

\section{Time Boundedness}

The presence or absence of time bounds on networks affects the threat of opportunism. Alliances designed to operate for a pre-specified length of time are more vulnerable to (ex-post) opportunistic behavior then the openended alliances where the potential gains from future collaboration provide a safeguard against opportunistic behavior designed to capture more proximate payoffs (Telser, 1980). Parkhe (1993) reveals that long time horizons decrease social uncertainty- the likelihood of opportunistic exploitation. By contrast, time-bound alliances do not feature the same 'shadow of the future' and do not support a tit-for-tat equilibrium that can keep opportunism in check (Axelrod, 1984). Here, owing to a myopic mind-set, the opportunistic partner(s) are more prone to seek a short-run maximization of their individual goals. The attainment of collective interests assumes a subservient role and is preferred to the extent it is perceived to be instrumental for the maximization of their respective self-interests.

\section{Degree Of Asset Specificity}

Mutual hostages are dedicated investments such as assets, human resources, specialized strategies and capital equipment that are difficult to move and redeploy in other relationships (Williamson, 1979). By developing mutual hostages, the partners create what economists call "self-enforcing contracts" because each party loses an incentive to cheat the other and instead gains a powerful motive to stay in the relationship and make the most of it (Klien, 1996). However, the value of TSAs is substantially reduced if the relationship is terminated because of opportunism (Doney and Cannon, 1997). Therefore, high asset specificity may spur (ex-post) opportunism as dedicated investments made by one party create scope for the other to renegotiate the contract opportunistically when circumstances change.

\section{Mobility, Transparency \& Intangibility/Contractibility Of Resources}

Some partners enter into a collaborative relationship with (ex-ante) intent to appropriate technology and know-how (Hamel et al., 1989). The pooled resource interdependence sometimes urges network members to draw upon their maximum even strategic resources in order to create transaction efficiencies, leaving greater opportunities for (ex-post) resource appropriation for opportunistic players especially when considerable differential resource transparency is there. If the resources/capabilities are too much transparent i.e. the causal ambiguity is absent, it becomes fairly easy for opportunistic players to imitate these capabilities that ultimately leads to the erosion of competitive advantage. This adverse effect is still more probable in the face of differences in the absorptive capacity; when the opportunistic player creates a 'hold out' after completing his learning at a faster speed. Many firms outsourced portions of their value chain only to find that they 'hollowed out' their core competencies and were later abandoned by their partners (Byrne et al., 1993). Therefore, in order to sustain comparative advantage, the firms need to protect their dynamic capabilities from copying by the competitors especially those with whom they get engaged as closed collaborative ties.

\section{Distribution Of Ownership, Control \& Decision Rights}

Whereas the under-allocation of ownership, control and/or decision rights counts upon motivation in partners, the opposite can make the focal firm more vulnerable to (ex-post) cheating and moral hazards by lessening its control. Decentralized decision rights create numerous opportunities for misaligned incentives and the network partnerships are no strangers to strife (Eccles and Crane, 1987; Rockert and Short, 1990). When the focal firm overallocates the property rights, opportunistic hazards mount especially when efficient monitoring and control is not put in place. Therefore, it is important for the focal firms to restrict access of the subscriber to the core attributes of its 
strategic dynamic capabilities. The absence of casual ambiguity makes it difficult to do so, thus making it easy for the opportunistic players to extra-leverage and/or imitate such resources which might result in the vanishing of competitive advantage.

\section{Information Asymmetry}

As teams of self-interested agents, networks mostly suffer from incentive problems with respect to surplus or 'public goods' jointly created but separately consumed. When a partner has private or asymmetric information, he can misrepresent the true state of affairs to secure more favorable terms in both the ex-ante and ex-post phases. Overoptimistic representation of capability is one such pitfall of asymmetric information. Partners usually overstate their private preferences when a good is provided from common sources but understate their private preferences when asked to ante up their share of cost (Alstyne, 1997). Networks are particularly vulnerable to this problem as some partners have a tendency to minimize their own efforts while free-riding on the efforts of others.

The structural 'indigestibility'/complexity can augment this problem by making it difficult to assess the relative contributions of partner's (Hennart and Reddy, 1997). In acquisition decisions, the existence of information asymmetry makes it difficult for the buying firms to ex-ante evaluate true worth of the targeted resources. The threat of opportunism sky rockets if the seller firms mis-represent the true worth of targeted assets. With the prevalence of such resource uncertainty, the buying firm will not be able to make an optimal acquisition decision. It may either make a too small offer to conclude the acquisition or may overpay. In the face of such uncertainties usually it prefers joint venture over the acquisition.

\section{Nature Of Dependence And/Or Interdependence}

Dependence is the expectation that considerable costs would be involved to replace an incumbent partner in case considerable TSI has been committed (Heide and John, 1988; Morgan and Hunt, 1994). To the extent that asymmetry in contribution occurs, dependence among partners escalates (Hamel et al., 1989). An asymmetric dependence provides an opportunity to the dominant partners to (ex-ante) negotiate for more favorable terms of engagement. Pooled interdependence can create significant (ex-post) cooperation problems because of the dangers of free-riding especially in the face of high information asymmetry. When several actors must contribute to a task, but it is hard to verify their marginal contributions, then collective under-investment of effort may occur (Alchian and Demsetz, 1972). On the other hand, reciprocal interdependence implies that recurrent exchange will take place, akin to a game. Opportunism in such ongoing games is avoided because of potential it creates for tit-for-tat strategies (Axelrod, 1984). If one partner proactively acts opportunistically, the other may also engage in reactive opportunism, the avoidance of which ensures a tit-for-tat game-theoretic control against (ex-post) opportunism.

\section{Power Asymmetry}

For collaborations to perpetuate, each party must contribute something distinctive (Hamel et al., 1989). Shifts in tastes and technologies can obsolete a skill base or critical complementary asset. Therefore, partners in collaborative arrangements need to be increasingly vigilant at maintaining their core competencies lest they become unattractive partners (Powel, 1990; Hamel et al., 1989). Forces that drove a network to take a partner can also cause it to decide the other way around when tastes and/or technologies change (Lazzirini et. al., 2006). Partly as a response, the disadvantaged party may have to reveal more of its proprietary know-how to maintain its attractiveness.

Asymmetry in partner attractiveness together with asymmetry in resource contribution creates power asymmetry which provokes the dominant partners to expect and appropriate greater payoffs. The powerful players who are not inequity-averse are sometimes able to appropriate larger share of the pie beyond their equitable share leaving a state of discomfort in the power recessive players. Vulnerabilities created by this situation lead to a 'hostage situation': the more dependent partner faces an inferior bargaining position, which further engenders opportunistic behavior from the advantaged party. If so happens, the disadvantaged partner has no option other then to renegotiate contractual terms to maintain a favorable position, or leave the collaboration all together (Lazzirini $e t$ al. 2006). 


\section{In-Equitable Incentive Structure}

Porter and Fuller (1985) argued that an alliance is stable for as long as contributions by each partner are perceived to be balanced and equitable. Networks fail when one or more partners perceive unfair treatment or an unsatisfactory ratio between compensation and contribution (Park and Ungson, 2001). As the members of a strategic network pool together the specialized know-how/resources to create synergies through a collaborative arrangement, the asymmetry in resource contributions, quite often, induces the resource dominant players to expect greater payoffs. Moreover, as already mentioned, the existence of information asymmetry makes it difficult to assess the relativity in contributions, thus making it easy for opportunistic members to free-ride over the contributions of others. Therefore, if the incentive structure fails to ensure (ex-post) distributive justice, the disadvantaged players are not only negatively reinforced to contribute in the successive cooperation cycles, but also begin to distrust the partner for such a display of opportunism.

\section{Nature Of Governance Mechanism}

Lieblien et al. (2002) reveals that firms' performance is contingent upon a better alignment between governance decisions and the degree of contractual hazards. For efficient governance, the mechanism of governance need to be closely aligned with transaction attributes and firm level capabilities (Williamson, 1991). Governance under-fit and over-fit adversely affects the network performance. When excessive safeguards are put in place, partners have to bear effects of increased bureaucratizing of social and economic life(Lange, 1938) as well as additional governance costs (Reuer and Arino, 2006); whereas insufficient safeguards can result instead in firms' increased exposure to (ex-post) opportunistic hazards. Strategic networks, therefore, have to make trade offs between efficiency and the vulnerability to opportunistic hazards.

\section{ADVERSARIES OF OPPERTUNISTIC BEHAVIOR}

Economic exchange confronts a number of exchange hazards or uncertainties caused by opportunistic behavior. Yamagishi et al. (1998) refer to this general class of exchange hazards as social uncertainty - "the risk of being exploited in social interactions". Under assumptions of self-interest, or its stronger forms (such as opportunism), win-win outcomes do not result due to actions motivated by the private interests of individual partners leading to a number of moral hazards and problems like prisoner's dilemma (Gulati et. al., 2005). Problems of 'hold-up', agency, and the 'tragedy of the commons' are all variations of prisoner's dilemma. Transaction cost economics (Klein et al. 1978; Williamson 1985) highlights the problem of "hold up" when one party consummates transaction-specific investments committed by the other party in exchange and then threatens to terminate the relationship thus creating the opportunity for her to bargain for higher rents. A similar problem has been observed in learning environments where an opportunistic partner creates a 'hold out' for the other partner after completing his learning at a faster speed due to its superior absorptive capacity. Exhibition of chauvinism (a manifestation of extreme self-centric behavior) increases agency costs. Moreover, the opportunist partners try to extra-leverage the common good while at the same time contributing less to the maintenance of such common pool resources. Opportunism is also witnessed in buyer-seller relationships where sellers misrepresent information about the quality of their products prior to the buyer's purchase - a manifestation of adverse selection (Akerlof, 1970). In addition, the sellers also exert low effort after buyers agree to acquire their services, a problem of moral hazard (Pauly, 1968).

Opportunism causes reduced cooperation, increased defections and reputation wear-outs. It leads to an asymmetric bargaining position and dissipation of firm-specific assets (Park and Ungson, 2001). Opportunistic behavior within a cooperative arrangement increases transaction cost as partners have to put in place various costlier control stipulations like complex explicit contracts to escape opportunistic hazards. These costs involve those in acquiring and processing information to craft contracts, administering and monitoring contractual promises, and enforcing contractual provisions. They also involve legal and organizational costs in coordinating activity and ensuring desirable behaviors. When these costs become insurmountable, the networks may not succeed. Besides these financial implications, opportunism- through tempering mutual trust and commitment- creates serious threats for the quality of social-embeddedness. For these reasons, controlling the problem of opportunism is so crucial to the sustainable superior performance of strategic networks. 


\section{CONTROLLING THE OPPERTUNISM}

Research in transaction cost analysis, resource based view, and the relational view of strategic networks have debated a lot on the efficacy of a host of formal and informal governance mechanisms like TSIs, explicit contracts, ownership and decision rights, relational norms etc. in dealing with opportunistic hazards like hold-up, agency, tragedy of commons etc. in a variety of contexts like strategic alliances, supplier-buyer partnerships, joint ventures, virtual organizations etc. (Williamson 1979, 85; Macneil 1980; Kaufman and Stern 1988; Dwyer and Oh 1988; Kogut 1988; Heide and John 1992; Klien 1996; Reuer and Arino, 2006). In the section to follow, I will present an exhaustive account of some formal and informal devices to control the problem of opportunism.

\section{Contracts As A Control Mechanism}

Explicit contract is the most pronounced protective device against possible opportunistic hazards in transaction cost economics. By providing formal rules and procedures to govern the relationship, these contracts serve as deterrence against possible exploitation since a violation here may lead to certain economic and legal consequences besides the loss of reputation. Especially when the likelihood of potential value loss increases due to investments in specific assets, firms find it highly appropriate to negotiate more complex contracts which serve not only as an insurance against breach and termination but also as the means through which such consequences or threats will be handled (Dyer, 1997; Poppo and Zenger, 2002). Even though this complexity may increase the bureaucratization in economic life (Lange, 1938), signal mistrust (Jap and Ganesan 2000; Gulati 2007), and increase the costs to negotiate, monitor, and enforce such contracts, yet it is considered quite efficient to reduce the costs and performance losses from exchange hazards such as hold-up, moral hazard, and resource appropriation (Macneil, 1978; Heide, 1994). Research by Young and Wilkinson (1989), however, has concluded that the disadvantages due to inflexibility and the perceptions of mistrust outweigh the advantages offered by specific guidelines and specification of sanctions for opportunistic behavior.

\section{Mutual Hostages As Control Mechanism}

Mutual hostages are dedicated investments such as assets, human resources, specialized strategies and capital equipment that are difficult to move and redeploy in other relationships (Williamson, 1979). Besides efficiency concerns, firms make investment in transaction-specific-assets (TSAs) to signal honorable intentions to the partners with respect to their trade relationships (Mishra et. al. , 1998). In the absence of trust or any possibility for successor projects, such investments can prove to be highly instrumental in maintaining at least the short term contracts (Kogut, 1988). By developing mutual hostages, the partners create what economists call "self-enforcing contracts" because each party loses an incentive to cheat the other and instead gains a powerful motive to stay in the relationship and make the most of it (Klien, 1996). As such, these investments are highly instrumental in achieving higher return on investment through accomplishment of synergistic performance in the collaboration. However, the value of TSAs is substantially reduced if the relationship is terminated due to opportunism (Doney and Cannon, 1997). Anyhow, complementing TSIs with common ownership, muted incentives, enhanced monitoring, and the threat of sanctions can mitigate this problem (Williamson, 1985).

There is yet another serious concern that warrants significant managerial attention. The firms need to be realistic in their assessments of opportunism risk specific to the dedicated investments since an over-assessment can lead to high opportunity cost by declining to commit to a relationship with an otherwise valuable partner (Jongwook and Mahoney, 2005). Thus, it is not only the economic costs of searching for partners, or monitoring and enforcing agreements but also the economic opportunity costs of potential value-creating transactions foregone that need to be taken into account while managing transaction-efficiency in strategic networks.

\section{Common Ownership As Control Mechanism}

A central tenant of transaction cost analysis is that investments in TSAs are better protected through vertical integration (Willaimson, 1979, 1985). Therefore, firms may consider owning their sources of supply or factor of distribution as a means of keeping opportunistic behaviors in check (Willaimson, 1985).

Vertical integration does it in three ways; 
1. The right to ownership permits use of more extensive monitoring and surveillance (Williamson 1975)

2. It offers the potential for a richer system of rewards and punishments (sanctions, taxes, etc.)

3. The organizational culture shared by parent organizations and subsidiaries provides common norms and values which help in aligning their interest (Rindfleisch and Heide, 1997).

As it is difficult to align interests of all individual units with the parent organization, the opportunism cannot altogether vanish with common ownership. It can prove more efficacious when complemented with other governance mechanisms.

\section{Game Theoretic Equilibrium}

Interdependencies result in a substantial potential for exploitation and conflicts because they often involve trade-offs among the goals of network partners (Eccles and Crane, 1987). To resolve such conflicts in cooperative relationships, Johnston and Lawrence (1988) make an explicit appeal to Axelrod's (1984) tit-for-tat game-theoretic principle;

1. Individually each partner should avoid being the first to game the system in order to build trust.

2. Reciprocate both cooperative and opportunistic maneuvering quickly.

3. Do not be too clever attempting to outsmart one's partners.

However, for this strategy to work, relationships must be sufficiently long or frequent (in contact) so as to allow multiple rounds of cooperation which ensure control through continuous assessment and review following the logic of "shadow of future" (Alstyne, 1997). Thorough continuous fair-play, partner firms develop a reputation for fairness or unscrupulousness that qualifies them for participation in future deals. Through repeated transactions, relationship can become symbiotic (Nolan et al., 1988) and trustworthy (Johnston and Lawrance, 1988; Perrow, 1993) as the potential collaborators assume that each will forbear from exploiting each other's vulnerabilities (Sabel, 1991).

\section{Relational Norms As Control Mechanism}

Norms are expectations about behavior that are partially shared by a group of decision makers and directed toward collective goals (Macneil, 1980; Thibaut and Kelly, 1959). Relational Exchange theory reveals relational norms as a distinct form of governance (the relational governance) that prescribes commitment and proscribes opportunism in exchange relationships (Mcneil, 1980; Morgan and Hunt, 1994; Joshi and Stump, 1999). 'Relational norms promote subordination of individual interests by engendering a win-win exchange atmosphere; and as the partners will not like to jeopardize it so they will refrain from acting opportunistically' (Heide and John, 1992). Inspired from the works of McNeil in 1980s in law, a handful number of researchers in social-contracting theory have espoused relational norms as an alternative to common ownership and contractual governance to resolve problems like hold-up, agency, and tragedy of commons (Granovetter, 1985; Gulati, 1995; Dyer and Singh, 1998; Poppo and Zenger, 2002). The extent of relational governance is gauged by strength of relational norms prevalent in the exchange (Noordewier et. al., 1990), where strength refers to the rigor of norms-mix as well as degree of normative compliance. Lower levels of rigor and compliance with relational norms can be equated with transactional or contractual governance (Ferguson et al., 2005).

In an operational sense, relational governance can be considered a single, higher order construct in a second order factor model where the first order are a set of highly correlated relational norms (Noordewier et al., 1990). A handsome number of such norms are revealed in the relationalism literature. For example, Mcneil (1983) posited that various levels of relationality can be tracked along a discrete-relational continuum, where each level features a different mix of relational norms such as role integrity, contractual solidarity, harmonization of relational conflict, supracontractual relations, and proprietary of means. Kaufman and Stern (1988) reduced Mcneil list to three i.e. solidarity, role integrity, and mutuality. Later studies added a host of other relational norms such as information exchange, participation, fairness, flexibility (Heide and John, 1992; Jap and Ganesan, 2000; Blios and Ivens, 2006) to Mcneil's list and revealed them to be positively associated with superior performance of various actors in a variety of business contexts (Macneil, 1980; Kaufman and Stern, 1988; Dwyer and Oh, 1988). The context of 
exchange can influence the relative importance of each norm in ensuring the desired performance levels (Pauline $e t$ al., 1999).

Establishing enduring relationships and supportive norms provides a protective device against deviant and opportunistic behaviors especially in bilateral exchanges with asymmetry both in the economic and relational power (Samoul, 2007). As relational norms evolve, they become internalized by the exchange partners (Kelman, 1958) and come to serve as moral controls that promote pro-relationship behaviors like commitment, and discourage detrimental unilateral behaviors such as opportunism (Joshi and Stump, 1999). To mature, relational norms require substantial up-front investment of time, money and personnel by the exchange partners (Frazier et. al., 1988). However, when developed they reduce the need for more elaborate safeguards, thus reduce the transaction cost. Maintenance of this fragile construct is still more problematic and can better be attained through a reciprocity-based socialization process (Crosby et. al., 1990; Johnston and Lawrance, 1988; Gundlach and Achrol, 1993).

\section{Identification As Cure}

As the boundary spanners and/or alliance manager may define their boundaries narrowly due to experiencing the 'dual citizenships', therefore strong identities (sense of belongingness/representing) should be constructed in order to escape the problem of self-interest maximization. Such identities help the individual members to conceive of boundaries for actions, resources, and purpose. Members tend to benchmark actions against the identity and use peer pressure to sanction the deviant behaviors: the nail that sticks up is the one hammered down. For this purpose, the partners need to develop 'shared goals' (Rockart and Shot, 1991), a common background' (Powel, 1991), and a 'collective vision' (Mills, 1991). Moreover, fear of shame, recognition and peer pressure play significant role in identity maintenance. When group integrity and identity are destroyed, the networks as society badly suffer (Alstyne, 1997). Network organizations can pursue extra curricular activities to socialize partners in order to cement organizational identity.

\section{Trust As Control Mechanism}

From a relational perspective, interorganizational trust has been defined as the expectation that an actor 1) can be relied on to fulfil obligations (Anderson and Weitz 1989), 2) will behave in a predictable manner, and 3) will act and negotiate fairly when the possibility for opportunism is present (Anderson and Narus 1990, Bromiley and Cummings 1995). In organizational economics literature, trust has been theorized to reduce opportunistic behaviours, and hence transaction cost of exchange, ultimately resulting in more efficient governance (Bromiley and Cummings 1995; Poppo et. al. 2008). As the use of a contract may signal distrust, thereby undermining the development of relational exchange and perhaps encouraging opportunistic behaviour between exchange partners (Fehr and Gachter, 2000; Ghoshal and Moran, 1996; Malhotra and Murnighan, 2002; Sitkin and Roth, 1993), Gulati and Nickerson (2007) argue that 'trust can substitute for hierarchical contracts in many exchanges and serves as an alternative control mechanism'. In context of industrial districts, Oba and Sermerciöz (2005) concluded that 'trust becomes a low cost substitute for contracts; entrepreneurs establish reliable relations and have confidence in each other because they know that information about malfeasance will be disseminated quickly, good or bad deeds will be reciprocated and those who defect will be expelled from the district; in other words, trustworthy behavior is a rational choice'. In addition, a rich body of research suggests that trust may substitute for formal governance if the cooperative behavior trust generates offers a less costly and more effective safeguard than complex contracts or vertical integration (Bradach and Eccles, 1989; Dyer, 1997; Gulati, 2007; Zaheer and Venkatraman, 1995).

\section{Long-Term Commitment As A Cure}

Commitment refers to an attitude that reflects the desire to continue a valued relationship (Moorman et. al., 1992) and a willingness to make short-term sacrifices to maintain that relationship (Anderson and Weitz, 1992). Long-term commitment can generate a state of cooperation between partners due to the shadow of the future' (Axelrod, 1984). Cooperation between the actors is more likely when they anticipate doing business with one another well into the future. However, game-theorists suggest that committed relationships discourage opportunistic behavior whenever expected payoffs from continued exchange surpass short-term gains from defection (Abreu, 1988; Axelrod, 1984; Taylor, 1987). 
However, highly contextual to the settings, relationships embedded in close social connections "at times facilitate and at times derail exchange," creating what Uzzi (1997) designates the "paradox of embeddedness". When exchange value uncertainty (the possibility that the value of transacting with a particular actor will decrease in the future) rises, the perceived value gap between the current and an alternative relationship becomes quite large (Thibaut and Kelley, 1959; Yamagishi et al., 1998). In this situation, the immobility resulting from firms' overattachments may preclude adjustments in the social structure required for exchange transactions to yield fair returns to all parties (Blau, 1964). To increase or at least sustain performance under these circumstances, the focal actors need continuous coupling and decoupling of actors to ensure an efficient adaptation (Jones et al., 1997). Therefore, rising exchange value uncertainty implicates social mobility so that actors can flexibly access more attractive exchange opportunities beyond existing, close ties. But there can also be cost inherent in lowering exchange value uncertainty through switching exchange partners as Helper (1991) found that U.S. automakers created a "legacy of mistrust" with their suppliers as a consequence of an ongoing solicitation of competing bids and a general propensity to switch exchange partners.

\section{PLURALISM IN CONTROL}

Each governance mechanism differs in its efficacy to limit opportunism especially when put in place solely. A central premise of TCA is the use of multiple governance mechanism to limit display of opportunistic behavior by exchange partners (Williamson, 1985). In some cases, these mechanisms act as functional substitutes of one another (Stump and Heide, 1996), whereas in others, these are used simultaneously (Brown et. al., 2000). Firms may employ multiple mechanisms for governing transactions (Bradach and Eccles, 1989) contingent upon the extent of TSIs, environmental uncertainty, nature of dependence etc. (Brown et al., 2000).

Governance mechanisms are often used simultaneously to take advantage of their differential impacts (Weitz and Jap, 1995). They supplement and reinforce each other. Ownership and TSIs can limit opportunism through the threat of sanctions as Brown et al. (2000) noted; 'the sanctions inherent in TSA governance reinforce and supplement the rewards and punishment of ownership'. Ownership and relational norms do it through shared norms and values'. Relational exchange and TSA investment do it through promoting volunteer actions, the former to preserve the relationship and the later to preserve the investments. Moreover, relational exchange being the positive form of governance offsets the negativities that may result from the use of fiat (sanctions) and/or mutualhostageship. So the network managers should emphasize the use of relational norms more then the use of ownership or TSIs in their approach to govern strategic networks.

\section{CONCLUSION AND FUTURE RESEARCH}

The success of an interfirm relationship, to a great extent, depends upon quality of the ecosystem in which transactions take place. An ideal ecosystem characterizes higher levels of social, economic and political egalitarianism where the participating nodes equitably benefit from their efforts to arrive at win-win solutions to their economic and social problems, and ultimately end-up attaining Pareto-efficiency i.e. a state which leaves every node at least as better-off (I will say in social, economic, and political sense) as they were before becoming a part of that structural arrangement. Besides weird coordination, opportunism being the key antecedent to reduced collaboration can be considered the major predicament to achieving this end. A number of behavioral and structural factors can spur and/or facilitate opportunistic behaviors in the partners. Such factors include history of collaboration, perceived life and LTV of networks, partnership uncertainty, perceived fairness, inequity aversion and trust, chauvinism, time boundedness (contracts), degree of asset specificity, inequitable incentive structure,mobility, transparency and contractibility of resources, sequential and/or reciprocal interdependence and asymmetries in power, resource contributions, rewards, ownership and control rights. Some of them operate through both the ex-ante and ex-post phases of a network's life cycle, whereas some may have more influence in any one of these phases. Opportunism 1) causes problems like hold up, agency, 'tragedy of commons', adverse selection, 2) leads to decreased transaction efficiency and wear-out in trust, commitment and cooperation, and ultimately 3) adversely affects the strategic networks' bottom line. The problem of opportunism can be effectively addressed by aligning partners' interests through formal mechanisms such as explicit contracts, common ownership, mutual hostages, as well as informal mechanisms such as promotion of relational norms, identification, trust and 
commitment. Focal firms may, sequentially or simultaneously, employ multiple mechanisms for controlling opportunism contingent upon the extent of TSIs, environmental uncertainty, nature of dependence etc.

A valuable future research endeavor may be to conceptualize and operationalize the 'propensity to opportunism' construct. The development of such a scale will enable collaboration-seekers to gauge the potential for opportunism in the potential candidate for collaboration so as to minimize the possibility of adverse selection. The back-ground conditionals revealed in this paper can prove to be an important input for such a research endeavor.

\section{AUTHOR INFORMATION}

Muhammad Zafar Yaqub is a doctoral scholar at University of Vienna, Austria. He received his Master degree in Business Administration (with distinction) from Bahauddin Zakariya University, Multan in 1995. Afterwards, he received his Master degrees in Economics (1999), and Political Science (2005) from The Islamia University of Bahawalpur. He is serving as Assistant Professor of Management Sciences in The Islamia University of Bahawalpur.

\section{REFERENCES}

1. Abreu D., On the Theory of Infinitely Repeated Games with Discounting, Econometrica, Vol. 56, pp. 383396, 1988.

2. Akerlof G., The Market for 'Lemons': Qualitative Uncertainty and the Market Mechanism, Quarterly Journal of Economics, Vol. 84, pp. 488-500, 1970.

3. Alchian A., and H. Demsetz, Production, Information Costs, and Economic Organization, American Economic Review, Vol. 62, pp. 777-795, 1972.

4. Aldrich, H.E. and P. Marsden, Environments and Organizations, in Handbook of Sociology, N.J. Smelser, Editor. Sage: Beverly Hills, pp. 361-392, 1988.

5. Alstyne, M.V., The State of Network Organization: A Survey in Three Frameworks, Journal of Organizational Computing, Vol. 7, No. 3, 1997.

6. Anderson E., and S.D. Jap, The Dark Side of Close Relationships, MIT Sloan Management Review, Vol. 46, No. 3, p. 75, 2005.

7. Anderson E., and B. Weitz, Determinants of Continuity in Conventional Industrial Channel Dyads", Marketing Science, Vol. 8, No. 4, pp. 310-323, 1989.

8. $\quad$ Anderson J.C., and J.A. Narus, A Model of Distributor Firm and Manufacturer Firm Working Partnerships", Journal of Marketing, Vol. 54, No. 1, pp. 42-58, 1990.

9. Arendt H., Imperialism, Nationalism, Chauvinism, Review of Politics, Vol. VII, pp. 443-469, 1945.

10. Axelrod R., The evolution of cooperation, Basic Books, New York, 1984.

11. Baker, W.E., The Network Organization in Theory and Practice, in Networks and Organizations, N. Nohria and R.G. Eccles, editors., Harvard Business School Press: Boston, MA. P. 397-429, 1993.

12. Bensaou M., and N. Venkatraman, Configurations of Interorganizational Relationships: A Comparison Between U.S. and Japanese Automakers, Management Science, Vol. 41, No. 9, pp. 1471-1492, 1995.

13. Blau, P., Exchange and power in social life, Wiley, New York, 1964.

14. Bleeke J., and D. Ernst, Collaborating to Compete, John Wiley and Sons, New York, 1979.

15. Blios K.J., and B.S. Ivens, Measuring Relational Norms: Some Methodological Issues", European Journal of Marketing, Vol. 40, No. 3/4, pp. 352-65, 2006.

16. Bradach J., and R. Eccles, Rice, Authority, and Trust: From Ideal Types to Plural Forms, Annual Review of Sociology, Vol. 15, pp. 97-118, 1989.

17. Bromiley, P., and L.L. Cummings, Organizations with Trust, in Bies, R., Lemicke, R., Sheppard, B. (Eds),Research in Negotiations, 5th ed., JAI Press, Greenwich, CT, pp.219-47, 1995.

18. Brown J.R., C.S. Dev, and D-J Lee, Managing Marketing Channel Opportunism: The Efficacy of Alternative Governance Mechanisms, Journal of Marketing, Vol. 64, No. 2, pp. 51-65, 2000.

19. Buckely P., M. Casson, A Theory of Cooperation in International Business, in Cooperative Strategies in International Business. F. Contractor and P. Lorenge. Eds., Lexington Books, Lexington, MA, 1988.

20. J.A. Byrne, R. Brandt, and O. Port, The Virtual Corporation, in Business Week, pp. 98-103, 1993. 
21. Crosby L.A., K.R. Evans, and D. Cowels, Relationship Quality in Service Selling; an Interpersonal Influence Perspective, Journal of Marketing, Vol. 54, pp. 68-81,1990.

22. Das T.K., and B.S.Teng, Instabilities of Strategic Alliances: An Internal Tensions Perspective,” Organization Science, Vol. 11, No. 1, pp. 77-101, 2000.

23. Doney P.M., and J.P. Cannon, An Examination of the Nature of Trust in Buyer-Seller Relationships, Journal of Marketing, Vol. 61, No. 2, pp. 35-51, 1997.

24. Dwyer R.F., and S. Oh, A Transaction-cost Perspective on Vertical Contractual Structure and Interchannel Competitive Strategies, Journal of Marketing, Vol. 52, pp. 21-34, 1988.

25. Dyer, J. H., Effective Interfirm Collaboration: How Firms Minimize Transaction Costs and Maximize Transaction Value, Strategic Management Journal, Vol.18, No. 7, pp. 535-556, 1997.

26. Dyer, J.H., and H. Singh, The Relational View: Cooperative Strategy and Sources of Interorganizational Competitive Advantage, Academy of Management Review, Vol. 23, pp. 660-679, 1998.

27. Eccles R.G. and D.B. Crane, Managing Through Networks in Investment Banking, California Management Review, , Vol. 30, No. 1, pp. 176-195, 1987.

28. Eisenhard K.M., and C.B. Schcoonhoven, Resource-based View of Strategic Alliance Formation: Strategies and Social Effects in Entrepreneurial Firms, Organization Science, Vol. 7, pp. 136-150, 1996.

29. Fehr E., and K.M. Schmidt, "Fairness, Incentives, and Contractual Choices", European Economic Review, Volume 44, No. 4-6, pp. 1057-1068, 2000.

30. Fehr, E., and S. Gachter, Do Incentive Contracts Crowd out Voluntary Cooperation?, Working paper, Institute for Empirical Research in Economics, University of Zurich, 2000.

31. Ferguson R.F., M. Paulin, K. Möslein, and C. Müller, Relational Governance, Communication and the Performance of Biotechnology Partnerships", Journal of Small Business and Enterprise Development, Vol. 12, No. 3, pp. 395-409, 2005.

32. Frazier G.L., R.E. Spekman, and C.R. O’Neil, Just-in-time Exchange Relationships in Industrial Markets, Journal of Marketing, Vol. 52, No. 4, pp. 52-67, 1988.

33. Furubotn E.G, and R. Richter, Institutions and economic theory: The contribution of the new institutional economics, University of Michigan Press: Ann Arbor, MI, 1997.

34. Geringer J.M., and L. Herbert, Control and Performance of International Joint Ventures, Journal of International Business Studies, Vol. 18, pp. 235-254, 1989.

35. Ghoshal, S., and P. Moran Insead, Bad for Practice: A Critique of the Transaction Cost Theory, Academy of Management Review, Vol. 21, No. 1, pp. 13-47, 1996.

36. Granovetter, M., Economic Action and Social Structure: The Problem of Embeddedness, American Journal of Sociology, Vol. Vol. 91, pp. 481-510, 1985.

37. Gulati R., Alliances and Networks, Strategic Management Journal, Vol. 19, No. 4, pp. 293-317, 1998.

38. Gulati R., and N.Nickerson, Interorganizational Trust, Governance Choice, and Exchange Performance, Working Paper, 2007.

39. Gulati R., Network Location and Learning: The Importance of Network Resources and Firm Capabilities on Alliance Formation, Strategic Management Journal, Vol. 20, pp. 397-420, 1999.

40. Gulati R., K. Tarun, and N. Nohria, Unilateral Commitments and the Importance of Process in Alliances, Sloan Management Review, Vol. 53, pp. 61-69, 1994.

41. Gulati R., P. R. Lawrence, and P. Puranam, Adaptation in Vertical Relationships: Beyond Incentive Conflict, Strategic Management Journal, Vol. 26, No. 5, pp. 415-40, 2005.

42. Gulati, R., Does Familiarity Breed Trust? The Implications of Repeated Ties for Contractual Choice in Alliances, Academy of Management Journal, Vol. 38, pp. 85-112, 1995.

43. Gulati, R., Managing Network Resources: Alliances, Affiliations, and other Relational Assets, Oxford University Press, 2007.

44. Gundlach G.T., and R.S. Achrol, Governance in Exchange Contract Law and its Alternatives, Journal of Public Policy and Marketing, Vol. 12, No. 2, pp. 141-55, 1993.

45. Hamel G., Competition for Competence and Interpartner Learning within International Strategic Alliances, Strategic Management Journal, Vol. 12, pp. 83-103, 1991.

46. Hamel G., Y.L. Doz, and C.K. Prahalad, Collaborate with Your Competitors -- and Win, Harvard Business Review, Vol. 67, No. 1, pp. 133-139, 1989.

47. Heide J., and G. John, Does Norms Matter in Marketing Relationships?, Journal of Marketing, Vol. 56, No. 2, pp. 32-44, 1992. 
48. Heide J.B., Interorganizational Governance in Marketing Channels, Journal of Marketing, Vol. 58, No. 1, pp. 71-85, 1994

49. Helper, S., Strategy and Irreversibility in Supplier Relations: the Case of the U.S. Automobile Industry, Business History Review, Vol. 65, pp. 781-824, 1991.

50. Hennart J.F., and S. Reddy, The Choice between Mergers, Acquisitions and Joint Ventures: The Case of Japanese Investors in United States, Staregic Management Journal, Vol. 18, pp. 1-12, 1997.

51. Hill C.W.L., Cooperation, Opportunism, and the Invisible Hand: Implications for Transaction Cost Theory, Academy of Management Review, Vol. 15, pp. 500-513, 1990.

52. Jap S.D. and S. Ganesan, Control Mechanisms and the Relationship Life Cycle: Implications for Safeguarding Specific Investments and Developing Commitment, Journal of Marketing Research, Vol. 37, No. 2, pp. 227-245, 2000.

53. Jensen, M. C., and W. H. Meckling, Theory of the Firm: Managerial Behavior, Agency Costs and Ownership Structure, Journal of Financial Economics, pp. 305-360, 1976.

54. Johnston, R., and P.R Lawrence., Beyond Vertical Integration - The Rise of the Value-adding Partnership, Harvard Business Review, Vol. 66, No. 4, pp. 94-101, 1988.

55. Jones, C., W. S. Hesterly, and S. P. Borgatt, A General Theory of Network Governance: Exchange Conditions and Social Mechanisms, Academy of Management Review, Vol. 22, pp. 911-945, 1997.

56. Jongwook K., and T. Mahoney, Property Rights Theory, Transaction Costs Theory, and Agency Theory: an Organizational Economics Approach to Strategic Management, Managerial and Decision Economics, Vol. 26, No. 4, pp. 223-242, 2005.

57. Joshi A.W., and Stump R.L., The Contingent Effect of Specific Assets Investment on Joint Action in Manufacturer-Supplier Relationships, Journal of Academy of Marketing Science, Vol. 27, No. 3, pp. 291314, 1999.

58. Kaufman P.J., and L.W. Stern, Relational Exchange Norms, Perceptions of Unfairness, and Retained Hostility in Commercial Litigation, Journal of Conflict Resolution, Vol. 32, No. 3, pp. 534-52, 1988.

59. Kelman H.C., Compliance, Identification, and Internalization: Three Processes of Attitude Change, The Journal of Conflict Resolution (pre-1986), Vol. 2, pp. 51-60, 1958.

60. Klein B, The Economics of Franchise Contracts, Journal of Corporate Finance, Vol. 2, No. 1, pp. 9-37, 1995.

61. Klein B., Why Hold-ups Occur: the Self-enforcing Range of Contractual Relationships, Economic Inquiry, Vol. 34, pp. 444-463, 1996.

62. Klein B., and K. B Leffler, The Role of Market Forces in Assuring Contractual Performance, Journal of Political Economy, Vol. 89, pp. 615-641, 1981.

63. Klein B., R. A. Crawford, and A. Alchian, Vertical Integration, Appopriable Rents, and the Competitive Contracting Process, Journal of Law and Economics, Vol. 21, pp. 297-326, 1978.

64. Kogut B,. Joint Ventures: Theoretical and Empirical Perspectives, Strategic Management Journal, Vol. 9, pp. 319-332, 1988.

65. Kogut B, Joint Ventures and the Option to Expand and Acquire, Management Science, Vol. 37: pp. 19-33, 1991.

66. Kronman A., Contract Law and the State of Nature", Journal of Law, Economics, and Organizations, Vol. 1, No. 1, pp. 5-32, 1985.

67. Lange O., On the Economic Theory of Socialism, University of Minnesota Press, 1938.

68. Lazzirini, Miller and Zeneger, Dealing with the Paradox of Embeddedness: The Role of Contracts and Trust in Facilitating Movement out of Committed Relationships, Working Paper, 2006.

69. Leiblein M.J., J.J. Reuer, and F. Dalsace, Do Make or Buy Decisions Matter? The Influence of Organizational Governance on Technological Performance, Strategic Management Journal, Vol. 23, pp. 817-833, 2002.

70. Macneil, I. R., Contracts: Adjustment of Long-term Economic Relations Under Classical, Neoclassical, and Relational Contract Law, Northwestern University Law Review, Vol. 72, pp. 854-905, 1978.

71. Malhotra, D., and J. K. Murnighan, The Effects of Contracts on Interpersonal Trust, Administrative Science Quarterly, Vol. 47, No. (3/4), pp. 534-59, 2002.

72. McNeil I.R., The New Social Contract, Yale University Press, New Heaven, CT, 1980.

73. Mcneil I.R., Values in Contract, Northwestern University Law Review, Vol. 75, pp. 1018-63, 1983.

74. Merton, R.K., Social Theory and Social Structure, New York: Free Press of Glencoe, 1957. 
75. Mills D.Q., Rebirth of the Corporation,: John Wiley \& Sons: New York, 1991.

76. Mishra D.P., J.B. Heide, and S.G. Cort, Information Asymmetry and Levels of Agency Relationships, Journal of Marketing Research, Vol. 35, No. 3; p. 277-295, 1998.

77. Moorman C., Zaltman G., and Deshpande R., Relationships between Providers and Users of Market Research: Dynamics of Trust within and between Organizations, Journal of Marketing research, Vol. 29, pp. 314-28, 1992.

78. Morgan R.M. and S.D. Hunt, The commitment-trust Theory of Relationship Marketing, Journal of Marketing, Vol. 58, pp. 20-38, 1994.

79. Nolan R., A.J. Pollock, and J.P. Ware, Creating the $21^{\text {st }}$ Century Organization”, Stage by Stage, Vol. 8, No. 4, pp. 1-11, 1988.

80. Noordewier T.G., G.John, and J.R. Nevin, Performance Outcomes of Purchasing Arrangements in Industrial Buyer-Vendor Relationships, Journal of Marketing, Vol. 54, No. 4, pp. 80-93, 1990.

81. Nooteboom, B., H. Berger, and N. Noorderhaven, Effects of Trust and Governance on Relational Risk, Academy of Management Journal, Vol. 40, No. 2, pp. 308-338, 1997.

82. Oba B., and Semerciöz F., Antecedents of Trust in Industrial Districts: an Empirical Analysis of Inter-firm Relations in a Turkish Industrial District, Entrepreneurship \& Regional Development, Vol.17, No. 3, pp. $163-182,2005$.

83. Oxley J.E, Appropriability Hazards and Governance in Strategic Alliances: a Transaction Cost Approach, Journal of Law, Economics, and Organization, Vol. 13, pp. 387-409, 1997.

84. Park S.H., and G. Ungson, Interfirm Rivalry and Managerial Complexity: A Conceptual Framework of Alliance Failure, Organization Science, Vol. 12, No. 1, p. 37, 2001.

85. Parkhe A., The Structure of Strategic Alliances: A Game-theoretic and Transaction Cost Examination on the Dissolution of Joint Ventures, Academy of Management Journal, Vol. 39, pp. 279-307, 1983.

86. Paulin M., R.J. Ferguson, and A.M.A. Salazar, External Effectiveness of Service Management: A study of Business-to-business Relationships in Mexico, Canada and the USA", International Journal of Service Industry Management, Vol. 10, No. 5, p. 409, 1999.

87. Pauly, M., The Economics of Moral Hazard, American Economic Review, Vol. 58, pp. 31-58, 1968.

88. Perrow C., Small Firm Networks, in Networks and Organizations, N. Nohria and R.J. Eccles, Editors 1993, Harvard Business School Press, Boston MA, pp. 445-470, 1988.

89. Poppo, L., and T. R. Zenger, Do Formal Contracts and Relational Governance Function as Substitutes or Complements?, Strategic Management Journal, Vol. 23, No. 8, pp. 707-25, 2002.

90. Poppo L., K.Z. Zhou and S. Ryu, Alternative Origins to Interorganizational Trust: An Interdependence Perspective on the Shadow of the Past and the Shadow of the Future, Organization Science, Vol. 19, No. 1, pp. 39-56, 2008.

91. Porter M.E., and M.B. Fuller, Coalitions and Global Strategy, in Competition in Global Industries, Porter M.E.: Harvard Business School Press: Boston, pp. 315-344, 1986.

92. Powell W.W., Neither Market nor Hierarchy: Network Forms of Organization, Research in Organizational Behavior, Vol. 12, pp. 295-336, 1990.

93. Reuer J.J., and A. Arino, Contractual Complexity in Strategic Alliances, Working paper, 2006.

94. Reve, T., and L.W Stern, The relationship between interorganizational form, transaction climate and economic performance in vertical interfirm dyads", in Pellergrini, L., Reddy, S. (Eds), Marketing Channels: Relationships and Performance, Lexington Books, Lexington, MA, pp.75-102, 1986

95. Rindfleisch A., and J.B. Heide, Transaction Cost Analysis: Past, Present, and Future Applications, Journal of Marketing, Vol. 61, pp. 30-54, 1997.

96. Ring P.S., and A.H. Van De Van, Developmental Processes of Cooperative Interorganizational Relationships, Academy of Management Journal, Vol. 19, pp. 90-118, 1994.

97. Ring P.S., The Role of Contracts in Strategic Alliances, in Cooperative Strategies and Strategic Alliances, Contractor F.J., and Lorange P. (editors). Elsevier Science: London, UK, pp. 145-162, 2002.

98. Rockart, J. and J. Short, The Networked Organization and the Management of Interdependence, in The Corporations of the 1990s, M.S. Morton, Ed., pp. 189-216, 1991.

99. Sabel C., Moebius-Strip Organizations and Open Labor Markets: Some Consequences of the Reintegration of Conception and Execution in a Volatile Economy, in Social Theory for a Changing society, P. Bairdieu and J.S. Coleman, Editors., Westview Press: Boulder, pp. 23-61, 1991. 
100. Samouel P., Does Time Impact Relational Norms in Bilateral Exchange? The Small Business Case”, Journal of Small Business and Enterprise Development, Vol. 14, No. 1, p. 136, 2007.

101. Sitkin, S. B., and N. L. Roth, Explaining the Limited Effectiveness of Legalistic "Remedies" for Trust/distrust, Organization Science, Vol. 4, No. 3, pp. 367-94, 1993.

102. Taylor, M., The possibility of cooperation, Cambridge University Press, New York, 1987.

103. Telser L.G., A Theory of Self-enforcing Agreements, Journal of Business, Vol. 53, pp. 27-44, 1980.

104. Thibaut, J. W., and H. H. Kelley. The social psychology of groups. Wiley, New York, 1959.

105. Uzzi, B., Social Structure and Competition in Interfirm Networks: the Paradox of Embeddedness, Administrative Science Quarterly, Vol. 42, pp. 35-67, 1997.

106. Wall Street Journal, Jet Engine Pact of Rolls-Royce, GE is Scrapped. (November 20), 1986.

107. Weitz B.A., and Jap S.D., Relationship Marketing and Distribution Channels, Journal of the Academy of Marketing Science, Vol. 23, No. 4, pp. 305-320, 1995.

108. Williamson O.E., Transaction-cost Economics: the Governance of Contractual Relations, Journal of Law and Economics, Vol. 22, pp. 233-261, 1979.

109. Williamson O.E., The Economic Institutions of Capitalism: Firms, Markets, Relational Contracting. The Free Press, New York, 1985.

110. Williamson O.E., Comparative Economic Organization: The Analysis of Discrete Structural Alternatives, Administrative Science Quarterly, Vol. 36, pp. 269-296, 1991.

111. Yamagishi, T., K. S. Cook, and M. Watabe, Uncertainty, Trust, and Commitment Formation in the United States and Japan, American Journal of Sociology, Vol. 104, pp. 165-194, 1998.

112. Young L.C., and I.F. Wilkinson, The Role of Trust and Cooperation in Marketing Channels: A Preliminary Study, European Journal of Marketing, Vol. 23, No. 2, pp. 109-22, 1989.

113. Zaheer A., and N. Venkatraman. Relational Governance as an Interorganizational Strategy: An Empirical Test of the Role of Trust in Economic Exchange, Strategic Management Journal, Vol. 16, pp. 373-392, 1995.

114. Zajac E.J, and C. Olsen, From Transaction Cost to Transaction Value Analysis: Implications for the Study of Interorganizational Strategies, Journal of Management Studies, Vol. 30, pp. 131-145, 1993. 
NOTES 